\title{
ANALISIS MODEL MATEMATIKA PENYEBARAN PENYAKIT COVID-19 DENGAN LOCKDOWN DAN KARANTINA
}

\section{Analysis of Mathematical Models of Spread COVID-19 with Lockdown and Quarantine}

\author{
Muhammad Manaqib ${ }^{1 *}$, Maghvirotul Azizah ${ }^{2}$, Eti Hartati S. ${ }^{3}$, \\ Savira Pratiwi ${ }^{4}$, Raza Aqil Maulana ${ }^{5}$
}

1,2,3,4,5 Prodi Matematika, Fakultas Sains dan Teknologi, Universitas Islam Negeri Syarif Hidayatullah Jakarta Jl. Ir. H. Djuanda No. 95, Tangerang Selatan, 15412, Indonesia

Corresponding author e-mail: 1*muhammad.manaqib@uinjkt.ac.id

\begin{abstract}
Abstrak
Penelitian ini menggembangakan model matematika penyebaran penyakit COVID-19 SEIR dengan lockdown dan karantina. Pembentukan model diawali dengan membuat asumsi dan diagram kompartemen alur penyebaran COVID-19 dengan lockdown dan karantina. Kemudian dibentuk sistem persamaan diferensial nonlinear berdasarkan diagram kompartemen tersebut. Analisis sistem dilakukan dengan menentukan titik ekuilibrium dan bilangan reproduksi dasar $\left(R_{0}\right)$. Hasilnya diperoleh dua buah titik ekuilibrium yakni titik ekuilibrium bebas penyakit yang eksistensinya tanpa syarat dan titik ekuilibrium endemik yang eksistensinya bergantung pada bilangan reproduksi dasar $\left(R_{0}>1\right)$. Selanjutnya, analisis kestabilan titik ekuilibrium bebas penyakit menggunakan analisis nilai eigen matriks Jacobi dan Kriteria Routh-Hurwitz diperoleh titik kestimbangan bebas penyakit bersifat stabil asimtotik lokal jika $R_{0}<1$. Terakhir simulasi model dilakukan untuk memberikan gambaran geometris dari solusi dan untuk mendukung teorema yang diperoleh. Hasil simulasi numerik yang dilakukan mendukung hasil analisis dinamik yang diperoleh.
\end{abstract}

Kata Kunci : Lockdown, Karantina, COVID-19, Bilangan Reproduksi Dasar, dan Kestabilan Titik Ekuilibrium

\begin{abstract}
This research develops a mathematical model for the spread of the COVID-19 SEIR disease with lockdown and quarantine. The model development begins with making assumptions and compartment diagrams for the spread of COVID-19 with lockdown and quarantine. Afterwards a system of nonlinear differential equations based on the compartment diagram is formed. System analysis is performed by determining the equilibrium point and the basic reproduction number $\left(R_{0}\right)$. The results yield two equilibrium points, i.e. the disease-free equilibrium point whose existence is unconditional and the endemic equilibrium point whose existence depends on the basic reproduction number $\left(R_{0}>1\right)$. Furthermore, the analysis of the stability of the disease-free equilibrium point using the analysis of the eigenvalues of Jacobi matrix and the Routh-Hurwitz criterion show that the disease-free equilibrium point is locally asymptotically stable if $R_{0}<1$. Finally, model simulations are carried out to provide a geometric visualization of solution and also to support the obtained theorems. The resulting numerical simulations supports the obtained dynamic analysis results.
\end{abstract}

Keywords: Lockdown, Quarantine, COVID-19, Basic Reproduction Number, and Equilibrium Point Stability

Article info:

Submitted: $15^{\text {th }}$ March 2021 Accepted: $20^{\text {th }}$ July 2021

How to cite this article:

M. Manaqib, M. Azizah, E. Hartati S., S. Pratiwi, and R. A. Maulana, “ANALISIS MODEL MATEMATIKA PENYEBARAN PENYAKIT COVID-19 DENGAN LOCKDOWN DAN KARANTINA”, BAREKENG: J. Il. Mat. \& Ter., vol. 15, no. 03, pp. 479-492, Sep. 2021.

This work is licensed under a Creative Commons Attribution-ShareAlike 4.0 International License.

Copyright (C) 2021 Muhammad Manaqib, Maghvirotul Azizah, Eti Hartati S., Savira Pratiwi, Raza Aqil Maulana 


\section{PENDAHULUAN}

Akhir tahun 2019 dunia dihebohkan dengan mewabahnya infeksi penyakit baru yang menyerang sistem pernafasan (pneumonia) yang belum diketahui penyebabnya [1]. Selanjutnya pada awal tahun 2020, Tiongkok melaporkan kepada World Health Organization (WHO) terdapat 44 pasien dengan dugaan pneumonia baru di wilayah Kota Wuhan, Provinsi Hubei, Tiongkok [2]. Penularan penyakit ini masih belum diketahui penyebabnya, dugaan awal penyebaran penyakit ini berawal dari pasar makanan laut yang ada di Wuhan [3].Virus ini menyerang sistem pernafasan ketika imunitas sedang lemah, awal mulanya virus ini di temukan pada lansia yang mengalami gangguan pada saluran pernafasan dan gejala yang hampir sama dengan pneumonia yaitu demam, sesak nafas dan batuk dengan frekuensi yang sering.

Virus ini mulai teridentifikasi kode genetiknya yakni virus corona baru, yang diumumkan secara resmi oleh WHO pada 10 Januari 2020 [4]. Setelah penelitian dilakukan, diperoleh bahwa virus corona baru ini memiliki hubungan dekat dengan virus corona penyebab Severe Acute Respitatory Syndrome (SARS) dan Middle East Respiratory Syndrome (MERS) [5]. Diketahui bahwa SARS pernah mewabah di dunia tahun 2002 yang berawal dari Tiongkok dan MERS mewabah pada tahun 2012 yang berawal dari negara-negara Timur Tengah [6]. Selanjutnya, penyakit ini dinamakan sementara oleh WHO sebagai 2019 novel coronavirus (2019-nCoV) . Tidak lama kemudian beberapa provinsi di Tiongkok melaporkan pasien penyakit ini, bahkan beberapa negara di luar Tiongkok yakni Korea Selatan, Jepang, Thailand, Amerika Serikat, Makau, Hongkong, Singapura, Malaysia, Prancis, Jerman, Uni Emirat Arab, Vietnam dan Kamboja juga melaporkan pasien penyakit ini [7]. Diketahui bahwa pada pasien tersebut memiliki riwayat perjalanan dari Kota Wuhan dan Tiongkok.

WHO mengumumkan Kedaruratan Kesehatan Masyarakat yang Meresahkan Dunia/ Public Health Emergency of International Concern (KKMMD/PHEIC) pada tanggal 30 Januari 2020 [8]. Pada 11 Februari 2020 WHO menamakan virus ini sebagai COVID-19[9], yang mempunyai makna kata Co yakni corona, Vi yakni virus dan D yakni disease atau penyakit, 19 adalah tahun munculnya virus yakni 2019. Pada tanggal 11 Maret 2020 WHO mengumumkan COVID-19 telah menginveksi lebih dari 118.000 orang, menyebar di 114 negara dan mengakibatkan 4.291 orang meninggal. Atas dasar tersebut WHO menetapkan pandemi global untuk COVID-19 yang artinya COVID-19 telah menyebar luas di seluruh dunia[10]. Indonesia melaporkan kasus pertama kasus COVID-19 pada tanggal 2 Maret 2020. Pasien tersebut diduga tertular oleh warga negara Jepang yang berkunjung ke Indonesia. Penambahan jumlah kasus COVID-19 di Indonesia pun terus bertambah, sampai tanggal 11 Februari 2021 tercatat 1.191.990 kasus terkonfirmasi positif, 993.117 sembuh dan 32.381 menginggal dunia[11].

Untuk mengendalikan penyebaran COVID-19 di pusat penyebaran awal yakni kota Wuhan, Tiongkok melakukan lockdown kota Wuhan pada tanggal 23 Januari. Hal ini terbukti bahwa lockdown di Wuhan menunda terjadinya COVID-19 di kota-kota lain selama 2,91 hari dan mungkin telah mencegah lebih dari 700.000 kasus COVID-19 di luar Wuhan. Lockdown besar-besaran ini kemudian menjadi model bagi beberapa negara lain yang memerangi COVID-19 di seluruh dunia[2]. Banyak negara yang melakukan kebijakan lockdown di awal pandemi mulai dari negara-negara Eropa, Asia, Amerika, sampai Afrika[12]. Kebijakan lockdown kembali diberlakukan di beberapa negara seperti Lebanon, Inggris, Jepang, Thailand, dan Tiongkok pada awal tahun 2021 karena COVID-19 kembali mengganas.

Selain kebijakan lockdown, karantina atau isolasi pasien penderita COVID-19 juga diberlakukan pemerintah. Bagi pasien dengan resiko tinggi dikarantina rumah sakit sedangakan pasien tanpa gejala dikarantina di tempat-tempat yang disediakan pemerintah atau karantina mandiri di rumah. Rata-rata pasien COVID-19 harus melalukan karantina selama 14 hari sampai dinyatakan sembuh. Setiap orang yang melakukan perjalan ke luar negri juga diwajibkan untuk karantina di tempat-tempat yang ditentukan oleh pemerintah selama 14 hari [13].

Pertanyaan yang muncul seberapa efektifkah kebijakan lockdown dan karantina dalam pengendalian wabah COVID-19 dan faktor apakah yang berpengaruh dalam penyebaran COVID-19. Salah satu cara untuk menjelaskan permasalahan dalam dunia nyata adalah dengan memodelkan matematika [14], [15]. Pemodelan matematika banyak dikembangkan untuk menggambarkan dinamika populasi termasuk permasalahan epidemologi penyakit untuk memberi gambaran karakteristik persebaran suatu penyakit[16]. Pemodelan matematika COVID-19 mulai dikembangkan sejak pandemi terjadi di awal tahun 2020. Model dasar penyebaran COVID-19 adalah SIR dimana populasi dibagi menjadi sub pupulasi susceptible(S), infectious(I), dan removed (R) seperti yang dilakukan oleh Fosu et al.[17], Imran et al. [18], Ivanova \& Dospatliev[19], Liao et al. [20], dan Mitra[21]. Selanjutnya model SIR dikembangkan dengan menambahkan 
subpopulasi exposed/latent (E/L) diperoleh model SIR penyebaran COVID-19, seperti yang dikembangkan oleh Ala'raj et al.[22], Chinazzi et al. [23], Kai \& GuyPhilippeGoldstein [24], Kucharski et al.[25], Wang \& Liu [26], Wu, Leung, \&Leung [27], Yang et al.[28], dan Zhao, Stone, \&Gao [29].

Penelitian ini akan mengembangkan model penyebaran penyakit COVID-19, yakni model epidemi SEIR yang ditambahkan lockdown dan karantina. Model ini mengasumsikan adanya individu yang terpisah dengan individu rentan, dengan adanya lockdown sehingga individu tersebut tidak terinfeksi penyakit, selain itu setiap individu yang terinfeksi dapat melakukan karantina ataupun tidak. Berdasarkan model tersebut akan dicari titik kestimbangan dari masing-masing kompartemen dalam keadaan bebas penyakit dan endemik serta bilangan reproduksi awal. Selanjutnya dari titik kestimbangan bebas penyakit akan dicari kestabilannya menggunakan analisis nilai eigen matrik jakobi serta menggunakan Kriteria Routh-Hurwitz. Setelah itu akan dilakukan simulasi model untuk memberikan gambaran geometris dari solusi dan untuk mendukung teorema yang diperoleh. Terakhir, berdasarkan analisis model akan disusun rekomendasi untuk pengendalian wabah COVID-19.

\section{METODE PENELITIAN}

Berikut dijelaskan secara sistematis langkah-langkah yang dilakukan dalam penelitian ini:

1. Studi Literatur

Tahap ini peneliti melakukan kajian tentang pemodelan-pemodelan COVID-19 dari berbagai jurnal serta mencari informasi terbaru tentang COVID-19 di website WHO dan Komite Pengendalian COVID-19 dan Pemulihan Ekonomi Nasional (KPC PEN).

2. Pemodelan Matematika

Pertama akan disusun asumsi pembentukan model matematika penyebaran penyakit COVID-19 SIR dengan menambahkan faktor lockdown dan karantina, setelah itu disusun diagram kompartemen alur penyebaran COVID-19. Berdasarkan diagram kompartemen yang diperoleh dikonstruksi model matematikanya berbentuk sistem persamaan diferensial non linear.

3. Analisis Model

Model yang diperoleh akan dicari titik ekuilibrium dan bilangan reproduksi dasar. Selanjutnya dicari hubungan antara bilangan reproduksi dasar dengan eksistensi titik ekuilibrium dan kestabilannya. Kestabilan titik ekuilibrium digunakan untuk menganalisis perilaku solusi model yang dibentuk.

4. Simulasi Numerik

Simulasi numerik dilakukan untuk memberikan gambaran geometris dari solusi dan untuk mendukung teorema yang diperoleh.

5. Kesimpulan

Selanjutnya akan disusun rekomendasi dari penelitian ini bagaimana upaya yang dapat dilakukan untuk pengendalian wabah penyakit COVID-19 berdasarkan analisis model yang dilakukan.

\section{HASIL DAN PEMBAHASAN}

\subsection{Model Matematika}

Penelitian ini mengembangkan model matematika penyebaran penyakit COVID-19 dari model SEIR denga menambahkan lockdown dan karantina. Berikut disajikan asumsi sebagai dasar pembentukan model matematikanya.

1. Tidak ada migrasi ataupun emigrasi yang mengakibatkan populasi tertutup.

2. Diasumsikan laju kelahiran alami sama dengan laju kematian alami.

3. Individu akan terinfeksi apabila berhubungan kontak secara langsung maupun tidak langsung dengan individu terinfeksi.

4. Kompartemen lockdown hanya berisi individu rentan yang dibatasi pergerakannya untuk mengendalikan penyebaran virus. Bentuk pembatasan parsial maupun keseluruhan.

5. Individu yang yang terinfeksi akan melalui proses karantina ataupun tidak. Karantina yang dilakukan baik karantina mandiri di rumah ataupun karantina di rumah sakit. 
6. Individu yang terinfeksi dan individu yang dikarantina dapat sembuh dari penyakit.

7. Individu yang sembuh dari penyakit memiliki kekebalan tubuh sehingga tidak terkena penyakit ini kembali.

8. Kompartemen recovered adalah individu sembuh atau yang meninggal akibat penyakit.

Berikut secara sistematis disajikan pada Tabel 1 dan Tabel 2 variabel dan parameter model penyebaran penyakit COVID-19 dalam penelitian ini.

Tabel 1. Daftar variabel model penyebaran penyakit COVID-19 dengan lockdown dan karantina

\begin{tabular}{clll}
\hline Variabel & \multicolumn{1}{c}{ Definisi } & Syarat & \multicolumn{1}{c}{ Satuan } \\
\hline$S(t)$ & Jumlah individu rentan pada waktu ke- $t$. & $S(t) \geq 0$ & Individu \\
\hline$L(t)$ & $\begin{array}{l}\text { Jumlah individu yang dibatasi (lockdown) } \\
\text { pada waktu ke- } t \text {. }\end{array}$ & $L(t) \geq 0$ & Individu \\
\hline$E(t)$ & $\begin{array}{l}\text { Jumlah individu yang telat tertular (exposed) } \\
\text { oleh virus pada waktu ke- } t \text {. }\end{array}$ & $E(t) \geq 0$ & Individu \\
\hline$I(t)$ & Jumlah individu terinfeksi pada waktu ke- $t$. & $I(t) \geq 0$ & Individu \\
\hline$Q(t)$ & $\begin{array}{l}\text { Jumlah individu yang melakukan karantina } \\
\text { (Karantina) pada waktu ke-t. }\end{array}$ & $Q(t) \geq 0$ & Individu \\
\hline$R(t)$ & Jumlah individu recovered pada waktu ke- $t$ & $R(t) \geq 0$ & Individu \\
\hline
\end{tabular}

Tabel 2. Daftar parameter model penyebaran penyakit COVID-19 dengan lockdown dan karantina

\begin{tabular}{|c|c|c|c|c|}
\hline No & Parameter & Definisi & Syarat & Satuan \\
\hline 1. & $\mu$ & $\begin{array}{l}\text { Tingkat kelahiran atau kematian alami } \\
\text { populasi }\end{array}$ & $\mu \geq 0$ & $\frac{1}{\text { hari }}$ \\
\hline 2. & $\beta_{1}$ & $\begin{array}{l}\text { Tingkat individu rentan menjadi individu } \\
\text { exposed (Rata-rata penyebaran virus) }\end{array}$ & $\beta_{1} \geq 0$ & $\frac{1}{\text { hari }}$ \\
\hline 3 & $\eta$ & $\begin{array}{l}\text { Tingkat individu rentan menjadi individu } \\
\text { yang dibatasi (lockdown) }\end{array}$ & $\eta \geq 0$ & $\frac{1}{\text { hari }}$ \\
\hline 4 & $\delta$ & $\begin{array}{l}\text { Tingkat perpindahan dari individu yang } \\
\text { dibatasi (lockdown) menjadi rentan }\end{array}$ & $\delta \geq 0$ & $\frac{1}{\text { hari }}$ \\
\hline 5 & $\xi$ & $\begin{array}{l}\text { Tingkat individu laten menjadi individu } \\
\text { rentan. }\end{array}$ & $\xi \geq 0$ & $\frac{1}{\text { hari }}$ \\
\hline 6 & $\epsilon$ & $\begin{array}{l}\text { Tingkat individu laten menjadi individu } \\
\text { terinfeksi }\end{array}$ & $\epsilon \geq 0$ & $\frac{1}{\text { hari }}$ \\
\hline 7 & $\theta_{1}$ & Tingkat individu laten yang dikarantina. & $\theta_{1} \geq 0$ & $\frac{1}{\text { hari }}$ \\
\hline 8 & $\theta_{2}$ & Tingkat individu terinfeksi dikarantina & $\theta_{2} \geq 0$ & $\frac{1}{h a r i}$ \\
\hline 9 & $\alpha_{1}$ & $\begin{array}{l}\text { Laju individu yang terinfeksi sembuh dari } \\
\text { penyakit. }\end{array}$ & $\alpha_{1} \geq 0$ & $\frac{1}{h a r i}$ \\
\hline 10 & $\alpha_{2}$ & $\begin{array}{l}\text { Laju individu yang dikarantina sembuh } \\
\text { dari penyakit }\end{array}$ & $\alpha_{2} \geq 0$ & $\frac{1}{\text { hari }}$ \\
\hline
\end{tabular}

Model matematika dalam penelitian ini membagi individu populasi menjadi enam kompartemen, yaitu kompartemen individu rentan $(S)$, kompartemen individu lockdown $(L)$, kompartemen individu laten $(E)$, kompartemen individu terinfeksi $(I)$, kompartemen individu karantina $(Q)$, dan kompartemen individu sembuh $(R)$. Kompartemen populasi rentan adalah setiap individu yang rentan atau mungkin terpapar COVID-19. Sebagian individu rentan dilakukan lockdown atau penguncian wilayah sehingga inidividu di daerah ini bebas dari COVID-19. Dalam penelitian ini kompartemen populasi laten didefinisikan sebagai setiap individu rentan yang melakukan kontak dengan individu terinfeksi. Semua individu yang melakukan kontak dengan virus diklasifikasikan sebagai individu terpapar. Individu-individu ini mungkin akan menjadi 
terinfeksi atau kembali menjadi individu rentan terhadap virus. Kompartemen populasi terinfeksi adalah individu-individu yang terkonfirmasi positif COVID-19. Kompartemen karantina adalah setiap individu baik postif COVID-19 maupun yang kontak dengan pasien COVID-19 yang melakukan isolasi di rumah sakit ataupun isolasi mandiri di rumah.

Individu rentan dapat menjadi individu laten akibat kontak dengan individu terinfeksi dengan laju sebesar $\beta_{1}$. Kebijakan pemerintah dalam pengendalian wabah COVID-19 dengan melelakukan lockdown dengan laju sebesar $\eta$ dan laju pelepasan lockdown sebesar $\delta$. Individu laten yang terkonfirmasi positif COVID-19 atau menjadi individu terinfeksi dengan laju $\varepsilon$ dan yang terkonfirmasi negatif kembali menjadi rentan dengan laju $\xi$. Kesadaran individu laten dan individu terinfeksi dalam mengurangi penyebran COVID19 dengan melakukan karantina dengan laju sebesar $\theta$. Setiap individu yang lahir masuk ke kompartemen rentan dan setiap kompartemen mengalami kematian alami, keduanya dengan laju $\mu$. Tingkat kesembuhan individu dari penyakit COVID-19 sebesar $\alpha$.

Berikut disajikan skema penyebaran penyakit COVID-19 dengan pengaruh Lockdown dan karantina.

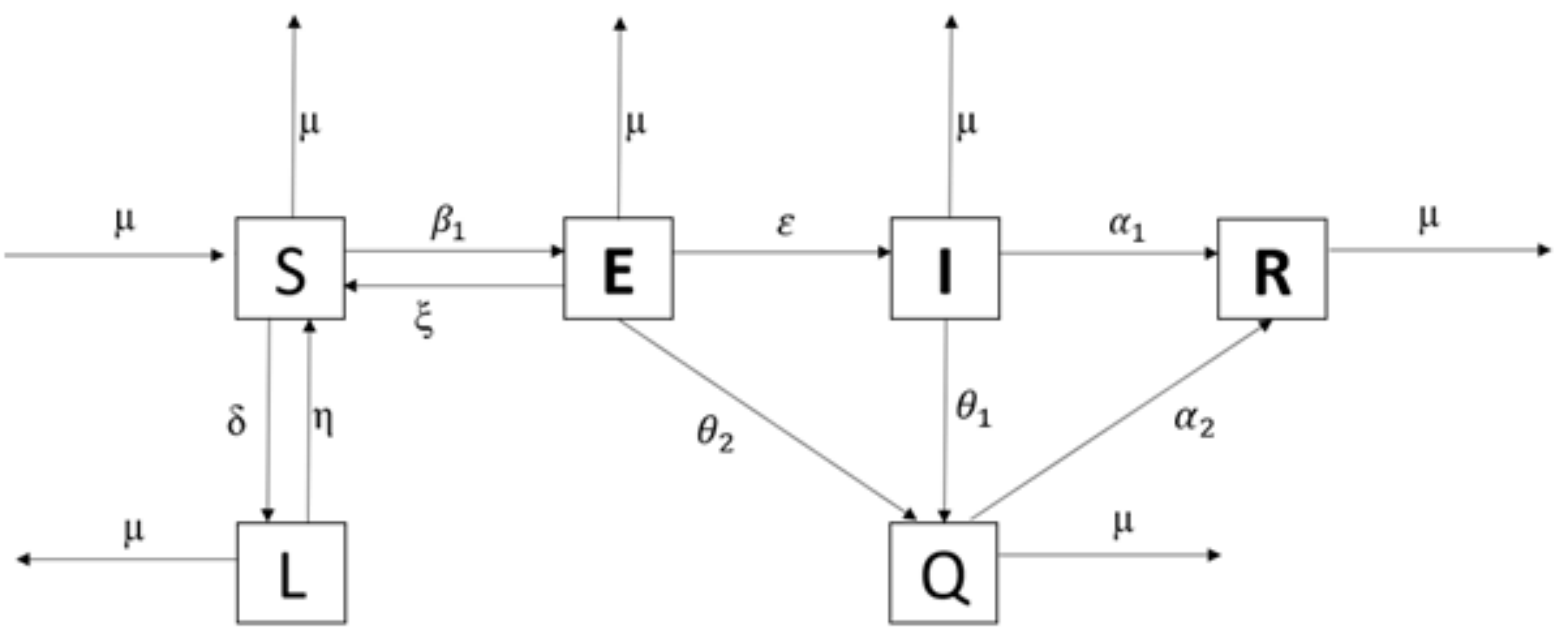

Gambar 1. Diagram transfer penyebaran penyakit COVID-19 dengan pengaruh lockdown dan karantina

Berdasarkan diagram transfer penyebaran penyakit COVID-19 dengan pengaruh lockdown dan karantina Gambar 1, dapat dibentuk model matematikanya berupa sistem persamaan diferensial biasa nonlinear berikut:

$$
\begin{aligned}
& \frac{d S}{d t}=\mu+\xi E+\delta L-\beta_{1} S I-\eta S-\mu S \\
& \frac{d L}{d t}=\eta S-(\mu+\delta) L \\
& \frac{d E}{d t}=\beta_{1} S I-\left(\mu+\varepsilon+\theta_{2}+\xi\right) E \\
& \frac{d I}{d t}=\varepsilon E-\left(\mu+\alpha_{1}+\theta_{1}\right) I \\
& \frac{d Q}{d t}=\theta_{1} I+\theta_{2} E-\left(\mu+\alpha_{2}\right) Q \\
& \frac{d R}{d t}=\alpha_{1} I+\alpha_{2} Q-\mu R
\end{aligned}
$$


dan $\boldsymbol{N}=\boldsymbol{S}+\boldsymbol{L}+\boldsymbol{E}+\boldsymbol{I}+\boldsymbol{Q}+\boldsymbol{R}$. Dapat ditunjukkan bahwa $\frac{d \boldsymbol{N}}{d t}=\frac{d S}{d t}+\frac{d L}{d t}+\frac{d E}{d t}+\frac{d I}{d t}+\frac{d Q}{d t}+\frac{d R}{d t}=\mathbf{0}$, maka $N(t)=k$ untuk $k$ bilangan real positif, maka $N(t)$ konstan.

Sistem (1) dapat dibentuk dalam model non-dimensional, yaitu dengan mengubah satuan individu pada setiap kompartemen menjadi proporsi sebagai berikut:

$$
s=\frac{S}{N}, l=\frac{L}{N}, e=\frac{E}{N}, i=\frac{I}{N}, q=\frac{Q}{N}, r=\frac{R}{N},
$$

sehingga diperoleh:

$$
s+l+e+i+q+r=\frac{S}{N}+\frac{L}{N}+\frac{E}{N}+\frac{I}{N}+\frac{Q}{N}+\frac{R}{N}=1 .
$$

Sistem (1) dapat dapat dibentuk dalam model non-dimensional berikut:

$$
\begin{aligned}
& \frac{d s}{d t}=\mu+\xi e+\delta l-\beta_{1} s i-\eta s-\mu s \\
& \frac{d l}{d t}=\eta s-(\mu+\delta) l \\
& \frac{d e}{d t}=\beta_{1} s i-\left(\mu+\varepsilon+\theta_{2}+\xi\right) e \\
& \frac{d i}{d t}=\varepsilon e-\left(\mu+\alpha_{1}+\theta_{1}\right) i \\
& \frac{d q}{d t}=\theta_{1} i+\theta_{2} e-\left(\mu+\alpha_{2}\right) q \\
& \frac{d r}{d t}=\alpha_{1} i+\alpha_{2} q-\mu r
\end{aligned}
$$

Variabel $s, l, e, i, q, r$ berturut-turut adalah proporsi invidu rentan, lockdown, laten, terinfeksi, karantina dan sembuh, sehingga dapat dibentuk himpunan invariant positif

$$
\Gamma=\{(s, l, e, i, q, r) \geq 0 \mid s+l+e+i+q+r=1\}
$$

sebagai domain sistem (3). Diperhatikan bahwa variable $r$ hanya muncul pada kompartemen $r$ dan tidak muncul pada kompartemen lainnya. Hal ini menunjukkan bahwa individu pada kompartemen $r$ tidak mempengaruhi perubahan individu pada kompartemen yang lain, maka kompartemen $r$ untuk sementara dapat diabaikan dari sistem. Sehingga sistem (3) dapat ditulis:

$$
\begin{aligned}
& \frac{d s}{d t}=\mu+\xi e+\delta l-\beta_{1} s i-\eta s-\mu s \\
& \frac{d l}{d t}=\eta s-(\mu+\delta) l \\
& \frac{d e}{d t}=\beta_{1} s i-\left(\mu+\varepsilon+\theta_{2}+\xi\right) e \\
& \frac{d i}{d t}=\varepsilon e-\left(\mu+\alpha_{1}+\theta_{1}\right) i \\
& \frac{d q}{d t}=\theta_{1} i+\theta_{2} e-\left(\mu+\alpha_{2}\right) q
\end{aligned}
$$

Diperoleh sistem (4) merupakan sistem sebagai model model matematika penyebaran penyakit COVID-19 dengan lockdown dan karantina 


\subsection{Analisis Model}

Analisis kestabilan titik ekuilibrium digunakan untuk menganalisis model. Berdasarkan [30] titik ekuilibrium adalah solusi sistem persamaan diferensial yang tidak bergantung dengan waktu. Sehingga titik ekulibrium sistem (4) diperoleh dengan menyelesaikan sistem (5) berikut:

$$
\begin{aligned}
& \mu+\xi e+\delta l-\beta_{1} s i-\eta s-\mu s=0 \\
& \eta s-(\mu+\delta) l=0 \\
& \beta_{1} s i-\left(\mu+\varepsilon+\theta_{2}+\xi\right) e=0 \\
& \varepsilon e-\left(\mu+\alpha_{1}+\theta_{1}\right) i=0 \\
& \theta_{1} i+\theta_{2} e-\left(\mu+\alpha_{2}\right) q=0
\end{aligned}
$$

Titik ekuilibrium bebas penyakit adalah kondisi dimana tidak ada individu terinfeksi penyakit yang dibahas dalam populasi, sehingga $i=0$. Dengan mensubstitusikan $i=0$ ke sistem (5) diperoleh titik ekuilibrium bebas penyakit $E_{1}=\left(\frac{\mu+\delta}{\mu+\delta+\eta}, \frac{\eta}{\mu+\delta+\eta}, 0,0,0\right)$.

Titik ekuilibrium endemik adalah kondisi dimana terdapat individu terinfeksi dalam populasi sehingga kompartemen $I$ pada titik ekuilibrium endemik yaitu $i^{*}>0$. Diperoleh titik ekuilibrium endemik sistem (5) adalah $E_{2}=\left(s^{*}, l^{*}, e^{*}, i^{*}, q^{*}\right)$

$$
\begin{aligned}
s^{*} & =\frac{\left(\mu+\alpha_{1}+\theta_{1}\right)\left(\mu+\varepsilon+\theta_{2}+\xi\right)}{\varepsilon \beta_{1}} \\
l^{*} & =\frac{\eta\left(\mu+\alpha_{1}+\theta_{1}\right)\left(\mu+\varepsilon+\theta_{2}+\xi\right)}{\varepsilon \beta_{1}(\mu+\delta)} \\
e^{*} & =\frac{\left(\mu+\alpha_{1}+\theta_{1}\right) i}{\varepsilon} \\
i^{*} & =\frac{\mu\left(\varepsilon \beta_{1}(\mu+\delta)-(\mu+\eta+\delta)\left(\mu+\alpha_{1}+\theta_{1}\right)\left(\mu+\varepsilon+\theta_{2}+\xi\right)\right.}{\beta_{1}(\mu+\delta)\left(\mu+\alpha_{1}+\theta_{1}\right)\left(\mu+\varepsilon+\theta_{2}\right)} \\
q^{*} & =\frac{\left(\theta_{1} \varepsilon+\theta_{2}\left(\mu+\alpha_{1}+\theta_{1}\right)\right) i}{\varepsilon\left(\mu+\alpha_{2}\right)}
\end{aligned}
$$

Selanjutnya akan ditentukan bilangan reproduksi dasar menggunakan matriks generasi berikutnya (next generation matrices) yang dikembangkan oleh [31].

1. Linierisasi terhadap subsistem terinfeksi ( $e, i$ dan $q$ ) pada titik ekuilibrium bebas penyakit.

$$
\begin{aligned}
J & =\left[\begin{array}{ccc}
\frac{d\left(\beta_{1} s i-\left(\mu+\varepsilon+\theta_{2}+\xi\right) e\right)}{d e} & \frac{d\left(\beta_{1} s i-\left(\mu+\varepsilon+\theta_{2}+\xi\right) e\right)}{d i} & \frac{d\left(\beta_{1} s i-\left(\mu+\varepsilon+\theta_{2}+\xi\right) e\right)}{d q} \\
\frac{d\left(\varepsilon e-\left(\mu+\alpha_{1}+\theta_{1}\right) i\right)}{d e} & \frac{d\left(\varepsilon e-\left(\mu+\alpha_{1}+\theta_{1}\right) i\right)}{d i} & \frac{d\left(\varepsilon e-\left(\mu+\alpha_{1}+\theta_{1}\right) i\right)}{d q} \\
\frac{d\left(\theta_{1} i+\theta_{2} e-\left(\mu+\alpha_{2}\right) q\right)}{d e} & \frac{d\left(\theta_{1} i+\theta_{2} e-\left(\mu+\alpha_{2}\right) q\right)}{d i} & \frac{d\left(\theta_{1} i+\theta_{2} e-\left(\mu+\alpha_{2}\right) q\right)}{d q}
\end{array}\right] \\
& =\left[\begin{array}{ccc}
-\left(\mu+\varepsilon+\theta_{2}+\xi\right) & \beta_{1} s & 0 \\
\varepsilon & -\left(\mu+\alpha_{1}+\theta_{1}\right) & 0 \\
\theta_{2} & \theta_{1} & -\left(\mu+\alpha_{2}\right)
\end{array}\right]
\end{aligned}
$$

Subtitusikan titik ekulibrium bebas penyakit $E_{1}=\left(\frac{\mu+\delta}{\mu+\delta+\eta}, \frac{\eta}{\mu+\delta+\eta}, 0,0,0\right)$ ke matriks $\boldsymbol{J}$, diperoleh: 


$$
J=\left[\begin{array}{ccc}
-\left(\mu+\varepsilon+\theta_{2}+\xi\right) & \frac{\beta_{1}(\mu+\delta)}{(\mu+\delta+\eta)} & 0 \\
\varepsilon & -\left(\mu+\alpha_{1}+\theta_{1}\right) & 0 \\
\theta_{2} & \theta_{1} & -\left(\mu+\alpha_{2}\right)
\end{array}\right]
$$

2. Dekomposisi matriks Jacobi $\boldsymbol{J}$ menjadi matriks transmisi $\boldsymbol{F}$ dan matriks Transisi $\mathbf{V}$

$$
\begin{aligned}
J & =\left[\begin{array}{ccc}
0 & \frac{\beta_{1}(\mu+\delta)}{(\mu+\delta+\eta)} & 0 \\
0 & 0 & 0 \\
0 & 0 & 0
\end{array}\right]-\left[\begin{array}{ccc}
-\left(\mu+\varepsilon+\theta_{2}+\xi\right) & 0 & 0 \\
\varepsilon & -\left(\mu+\alpha_{1}+\theta_{1}\right) & 0 \\
\theta_{2} & \theta_{1} & -\left(\mu+\alpha_{2}\right)
\end{array}\right] \\
& =\mathbf{F}-\mathbf{V}
\end{aligned}
$$

\section{Hitung $\boldsymbol{V}^{\mathbf{- 1}}$}

$$
V^{-1}=\left[\begin{array}{ccc}
\left(\mu+\varepsilon+\theta_{2}+\xi\right) & 0 & 0 \\
-\varepsilon & \left(\mu+\alpha_{1}+\theta_{1}\right) & 0 \\
-\theta_{2} & -\theta_{1} & \left(\mu+\alpha_{2}\right)
\end{array}\right]^{-1}
$$

$$
=\left[\begin{array}{ccc}
\frac{1}{\left(\mu+\varepsilon+\theta_{2}+\xi\right)} & 0 & 0 \\
-\frac{\varepsilon}{\left(\mu+\varepsilon+\theta_{2}+\xi\right)\left(\mu+\alpha_{1}+\theta_{1}\right)} & \frac{1}{\left(\mu+\alpha_{1}+\theta_{1}\right)} & 0 \\
\frac{\varepsilon \theta_{1}+\theta_{2}\left(\mu+\alpha_{1}+\theta_{1}\right)}{\left(\mu+\varepsilon+\theta_{2}+\xi\right)\left(\mu+\alpha_{1}+\theta_{1}\right)} & -\frac{\theta_{1}}{\left(\mu+\alpha_{1}+\theta_{1}\right)\left(\mu+\alpha_{2}\right)} & \frac{1}{\left(\mu+\alpha_{2}\right)}
\end{array}\right]
$$

3. $R_{0}$ diperoleh dengan cara menghitung radius spektral $(\rho)$ dari $\boldsymbol{F V}^{-\mathbf{1}}$ yaitu dengan mencari akar karakteristik terbesar dari $\boldsymbol{F V}^{\mathbf{- 1}}$.

$$
\begin{aligned}
\mathbf{F V}^{-1} & =\left[\begin{array}{ccc}
0 & \frac{\beta_{1}(\mu+\delta)}{(\mu+\delta+\eta)} & 0 \\
0 & 0 & 0 \\
0 & 0 & 0
\end{array}\right]\left[\begin{array}{ccc}
\frac{1}{\left(\mu+\varepsilon+\theta_{2}+\xi\right)} & 0 & 0 \\
\frac{\varepsilon+\frac{\varepsilon}{\left(\mu+\theta_{1}+\theta_{2}\left(\mu+\alpha_{1}+\theta_{1}\right)\right.}}{\left(\mu+\varepsilon+\theta_{2}+\xi\right)\left(\mu+\alpha_{1}+\theta_{1}\right)} & -\frac{1}{\left(\mu+\alpha_{1}+\theta_{1}\right)} & 0 \\
& =\left[\begin{array}{ccc}
-\frac{\left.\theta_{1}+\theta_{1}\right)\left(\mu+\alpha_{2}\right)}{\left(\mu+\alpha_{2}\right)} & \frac{1}{\left(\mu \beta_{1}(\mu+\delta)\right.}
\end{array}\right] \\
0 & \frac{\varepsilon \beta_{1}(\mu+\delta)}{\left(\mu+\varepsilon+\theta_{2}+\xi\right)\left(\mu+\alpha_{1}+\theta_{1}\right)(\mu+\delta+\eta)(\mu+\delta+\eta)} & 0 \\
0 & 0 & 0
\end{array}\right]
\end{aligned}
$$

$\operatorname{det}\left(\lambda \mathbf{I}-\mathbf{F} \mathbf{V}^{-1}\right)=0$ atau 


$$
\begin{aligned}
& \left|\begin{array}{ccc}
\lambda-\frac{\varepsilon \beta_{1}(\mu+\delta)}{\left(\mu+\varepsilon+\theta_{2}+\xi\right)\left(\mu+\alpha_{1}+\theta_{1}\right)(\mu+\delta+\eta)} & \frac{\varepsilon \beta_{1}(\mu+\delta)}{\left(\mu+\alpha_{1}+\theta_{1}\right)(\mu+\delta+\eta)} & 0 \\
0 & \lambda & 0 \\
0 & 0 & \lambda
\end{array}\right|=0 \\
& \Leftrightarrow\left(\lambda-\frac{\varepsilon \beta_{1}(\mu+\delta)}{\left(\mu+\varepsilon+\theta_{2}+\xi\right)\left(\mu+\alpha_{1}+\theta_{1}\right)(\mu+\delta+\eta)}\right) \lambda^{2}=0 .
\end{aligned}
$$

diperoleh $\lambda_{1}=\lambda_{2}=0$ dan $. \lambda_{3}=\frac{\varepsilon \beta_{1}(\mu+\delta)}{\left(\mu+\varepsilon+\theta_{2}+\xi\right)\left(\mu+\alpha_{1}+\theta_{1}\right)(\mu+\delta+\eta)}$. Sehingga diperoleh

$$
R_{0}=\frac{\varepsilon \beta_{1}(\mu+\delta)}{\left(\mu+\varepsilon+\theta_{2}+\xi\right)\left(\mu+\alpha_{1}+\theta_{1}\right)(\mu+\delta+\eta)}
$$

\section{Teorema 1}

(1) Titik ekuilibrium bebas penyakit $E_{1}$ ada tanpa syarat.

(2) Sedangkan titik ekuilibrium endemik $E_{2}$ ada jika $R_{0}>1$.

Bukti Sesuai syarat pembentukan model maka eksistensi suatu titik ekuilibrium ditunjukkan dengan setiap elemennya positif. Jelas bahwa $E_{l}$ semua elemennya positif. Untuk $E_{2}$ diperhatikan bahwa $s^{*}, l^{*}, e^{*}$ dan $q^{*}$ pada titik ekulibrium $E_{2}=\left(s^{*}, l^{*}, e^{*}, i^{*}, q^{*}\right)$ persamaan (6) positif jika dan hanya jika $i^{*}$ positif, sehingga perlu ditunjukkan $i^{*}>0$.

$$
\begin{aligned}
i^{*} & =\frac{\mu\left(\varepsilon \beta_{1}(\mu+\delta)-(\mu+\eta+\delta)\left(\mu+\alpha_{1}+\theta_{1}\right)\left(\mu+\varepsilon+\theta_{2}+\xi\right)\right)}{\beta_{1}(\mu+\delta)\left(\mu+\alpha_{1}+\theta_{1}\right)\left(\mu+\varepsilon+\theta_{2}\right)} \\
& =\frac{\mu\left(\frac{\varepsilon \beta_{1}(\mu+\delta)}{(\mu+\eta+\delta)\left(\mu+\alpha_{1}+\theta_{1}\right)\left(\mu+\varepsilon+\theta_{2}+\xi\right)}-1\right)}{\frac{\beta_{1}(\mu+\delta)\left(\mu+\alpha_{1}+\theta_{1}\right)\left(\mu+\varepsilon+\theta_{2}\right)}{(\mu+\eta+\delta)\left(\mu+\alpha_{1}+\theta_{1}\right)\left(\mu+\varepsilon+\theta_{2}+\xi\right)}} \\
& =\frac{\mu(\mu+\eta+\delta)\left(\mu+\alpha_{1}+\theta_{1}\right)\left(\mu+\varepsilon+\theta_{2}+\xi\right)}{\beta_{1}(\mu+\delta)\left(\mu+\alpha_{1}+\theta_{1}\right)\left(\mu+\varepsilon+\theta_{2}\right)}\left(R_{0}-1\right)
\end{aligned}
$$

Berdasarkan persamaan (8) $i^{*}>0$ jika dan hanya jika $R_{0}>1$.

Teorema 2 Jika $R_{0}<1$ maka titik ekuilibrium bebas penyakit $E_{1}$ sistem (4) stabil asimtotik lokal.

Bukti Analisis kestabilan titik ekulibrium bebas penyakit dilakukan dengan menganalisis nilai eigen matriks Jakobi pada titik ekuilibrium bebas penyakit.

$$
J_{(E)}=\left[\begin{array}{ccccc}
-\beta_{1} i-\eta-\mu & \delta & \xi & -\beta_{1} s & 0 \\
\eta & -(\mu+\delta) & 0 & 0 & 0 \\
\beta_{1} i & 0 & -\left(\mu+\varepsilon+\theta_{2}+\xi\right) & \beta_{1} s & 0 \\
0 & 0 & \varepsilon & -\left(\mu+\alpha_{1}+\theta_{1}\right) & 0 \\
0 & 0 & \theta_{2} & \theta_{1} & -\left(\mu+\alpha_{2}\right)
\end{array}\right]
$$




$$
\begin{gathered}
\quad\left|\lambda \mathbf{I}-\mathbf{J}_{\left(E_{1}\right)}\right|=0 \\
\Leftrightarrow\left[\begin{array}{ccccc}
\lambda+\eta+\mu & -\delta & -\xi & \beta_{1}\left(\frac{\mu+\delta}{\mu+\delta+\eta}\right) & 0 \\
-\eta & \lambda+\mu+\delta & 0 & 0 & 0 \\
0 & 0 & \lambda+\mu+\varepsilon+\theta_{2}+\xi & -\beta_{1}\left(\frac{\mu+\delta}{\mu+\delta+\eta}\right) & 0 \\
0 & 0 & -\varepsilon & \lambda+\mu+\alpha_{1}+\theta_{1} & 0 \\
0 & 0 & -\theta_{2} & -\theta_{1} & \lambda+\mu+\alpha_{2}
\end{array}\right]=0
\end{gathered}
$$

$\Leftrightarrow(\lambda+\eta+\mu)((\lambda+\mu+\delta)(\lambda+\eta+\mu)-(\eta \delta)) P=0$

dengan

$$
P=\left(\lambda+\mu+\varepsilon+\theta_{2}+\xi\right)\left(\lambda+\mu+\alpha_{1}+\theta_{1}\right)-\varepsilon\left(\beta_{1}\left(\frac{\mu+\delta}{\mu+\delta+\eta}\right)\right)
$$

Diperoleh $\quad \lambda_{1}=-\mu-\alpha_{2}, \lambda_{2}=-\frac{1}{2}\left[(\eta+2 \mu+\delta)-\sqrt{(\eta+2 \mu+\delta)^{2}-4 \mu(\eta+\mu+\delta)}\right], \lambda_{3}=-\frac{1}{2}[(\eta+$ $\left.2 \mu+\delta)+\sqrt{(\eta+2 \mu+\delta)^{2}-4 \mu(\eta+\mu+\delta)}\right]$ karena seluruh parameter yang digunakan positif dan $(\eta+2 \mu+\delta)>\sqrt{(\eta+2 \mu+\delta)^{2}-4 \mu(\eta+\mu+\delta)}$ maka jelas bahwa $\lambda_{1}<0, \lambda_{2}<0$ dan $\lambda_{3}<0$.

Selanjutnya tanda dari bagian real nilai eigen $\lambda_{4}$ dan $\lambda_{5}$ dianalisis dengan kriteria Routh-Hurwitz. Semua nilai eigen (9) akan bernilai negatif jika memenuhhi kriteria Routh-Hurwitz yaitua $a_{0}>0, a_{1}>0$, dan $a_{2}>0$ dengan $a_{0}=1, a_{1}=2 \mu+\alpha_{1}+\theta_{1}+\varepsilon+\theta_{2}+\xi, a_{2}=\left(\mu+\varepsilon+\theta_{2}+\xi\right)\left(\mu+\alpha_{1}+\theta_{1}\right)-\varepsilon \beta_{1}\left(\frac{\mu+\delta}{\mu+\eta+\delta}\right)$ dan $\Delta_{1}, \Delta_{2}$ dari matriks Routh Hurwitz bernilai positif, dengan $\Delta_{1}=\left|a_{1}\right|, \Delta_{2}=\left|\begin{array}{cc}a_{1} & a_{0} \\ 0 & a_{2}\end{array}\right|$. Semua nilai parameter yang digunakan positif maka jelas bahwa $a_{0}>0$ dan $a_{1}>0$. Dierhatikan

$$
\begin{aligned}
a_{2} & =\left(\mu+\varepsilon+\theta_{2}+\xi\right)\left(\mu+\alpha_{1}+\theta_{1}\right)-\varepsilon \beta_{1}\left(\frac{\mu+\delta}{\mu+\eta+\delta}\right) \times \frac{\left(\mu+\varepsilon+\theta_{2}+\xi\right)\left(\mu+\alpha_{1}+\theta_{1}\right)}{\left(\mu+\varepsilon+\theta_{2}+\xi\right)\left(\mu+\alpha_{1}+\theta_{1}\right)} \\
& =\left(\mu+\varepsilon+\theta_{2}+\xi\right)\left(\mu+\alpha_{1}+\theta_{1}\right)-\frac{\varepsilon \beta_{1}(\mu+\delta)\left(\mu+\varepsilon+\theta_{2}+\xi\right)\left(\mu+\alpha_{1}+\theta_{1}\right)}{(\mu+\eta+\delta)\left(\mu+\varepsilon+\theta_{2}+\xi\right)\left(\mu+\alpha_{1}+\theta_{1}\right)} \\
& =\left(\mu+\varepsilon+\theta_{2}+\xi\right)\left(\mu+\alpha_{1}+\theta_{1}\right)\left(1-R_{0}\right)
\end{aligned}
$$

maka $a_{2}>0$ jika dan hanya jika $R_{0}<1$. Selanjutnya untuk matriks Routh Hurwitz $\Delta_{1}=\left|a_{1}\right|>0$ dan $\Delta_{2}=\left|\begin{array}{cc}a_{1} & a_{0} \\ 0 & a_{2}\end{array}\right|=a_{1} a_{2}$ karena $a_{1}>0$ dan $a_{2}>0$ maka $\Delta_{2}>0$. Sehingga dapat disimpulkan determinan matriks Routh Hurwitz $\Delta_{1}$ dan $\Delta_{2}$ bernilai positif jika $R_{0}<1$. Dengan demikian persamaan (9) memenuhi kriteria Routh Hurwitz jika $R_{0}<1$. Sehingga dapat disimpulkan bahwa titik ekuilibrium bebas penyakit $E_{1}$ merupakan stabil asimtotik lokal jika $R_{0}<1$.

\subsection{Simulasi Model}

Simulasi model penyebaran penyakit Covid-19 dengan lockdown dan karantina dilakukan dengan menggunakan parameter dari beberapa penelitian. Secara sistematis ditampilkan pada Tabel 3, berikut: 
Tabel 3. Nilai - nilai Parameter simulasi numerik titik ekulibrium bebas penyakit

\begin{tabular}{lccc}
\hline No & Parameter & Nilai & Referensi \\
\hline 1. & $\mu$ & 0.0125 & {$[32]$} \\
\hline 2. & $\beta_{1}$ & 0.2 & {$[33]$} \\
\hline 3. & $\eta$ & 0.2 & Asumsi \\
\hline 4. & $\delta$ & 0.8 & Asumsi \\
\hline 5. & $\xi$ & 0.19200 & Asumsi \\
\hline 6. & $\varepsilon$ & 0.0007142857143 & {$[34]$} \\
\hline 7. & $\theta_{1}$ & 0.084 & {$[33]$} \\
\hline 8. & $\theta_{2}$ & 0.0039798 & {$[35]$} \\
\hline 9. & $\alpha_{1}$ & 0.099087 & {$[36]$} \\
\hline 10. & $\alpha_{2}$ & 0.11624 & {$[36]$} \\
\hline
\end{tabular}

Substitusi parameter pada Tabel 3 ke persamaan (7) diperoleh $\mathrm{R}_{0}=0.003448399240$. Simulasi sistem (4) dengan parameter pada Tabel 3 dan nilai awal $s(0)=0.47, l(0)=0.2, e(0)=0.12, q(0)=0.04, i(0)=$ 0.15 menggunakan Maple 2020 disajikan hasil simulasi pada Gambar 2, berikut:

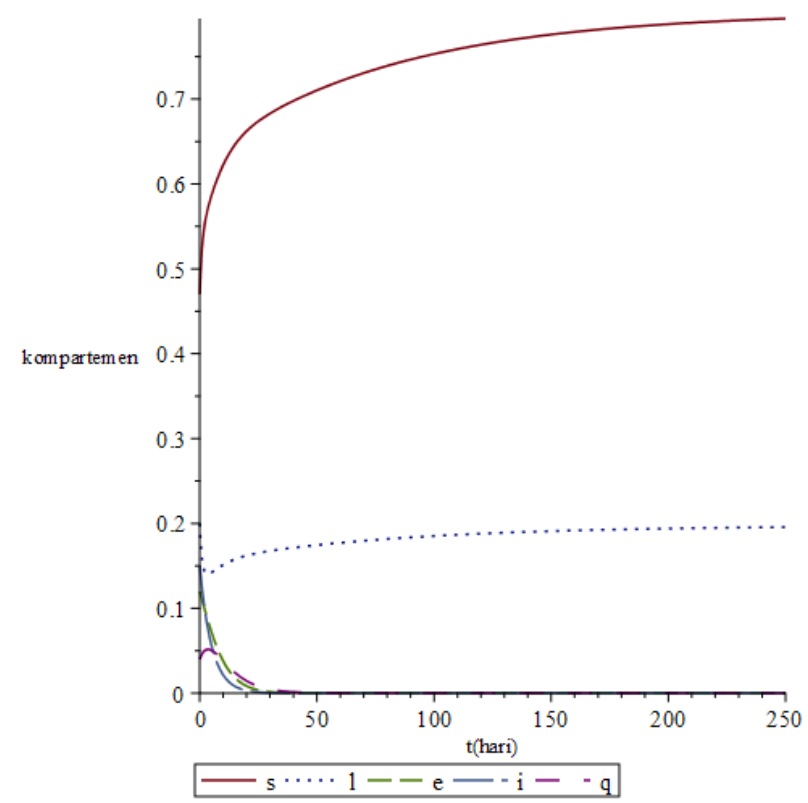

Gambar 2. Simulasi sistem (4) titik ekulibrium bebas penyakit

Berdasarkan simulai yang dilakukan populasi individu rentan (S) naik hingga hari ke - 500 menuju titik 0.8024691358 dan stabil pada titik tersebut. Populasi individu yang melakukan lockdown (L) naik hingga hari ke -500 menuju titik 0.1975308642 dan stabil pada titik tersebut. Populasi individu laten (E) turun hingga hari ke -40 menuju titik 0 dan stabil pada titik tersebut. Populasi individu terinfeksi (I) turun hingga hari ke -40 menuju titik 0 dan stabil pada titik tersebut. Populasi individu yang melakukan karantina (Q) turun hingga hari ke - 70 menuju titik 0 dan stabil pada titik tersebut. Kesimpulan yang dapat diperoleh dari simulasi ini penyakit akan menghilang dari populasi setelah hari ke-40 jika $R_{0}<1$, hasil ini sesuai dengan Teorema 2 yang telah dibentuk sebelumnya.

Selanjutnya akan dilakukan simulasi ketika $\mathrm{R}_{0}>1$. Masih digunakan parameter pada Tabel 3 tetapi parameter $\beta$ diperbesar menjadi 1, parameter $\delta$ diperkecil menjadi 0.2 dan $\eta$ diperbesar menjadi 0.8 , parameter $\varepsilon$ diperbesar menjadi 0.5 perhari, diperoleh nilai $\mathrm{R}_{0}=4.776217483$. Menggunakan nilai awal $\mathrm{s}(0)=0.4, \mathrm{l}(0)=0, \mathrm{e}(0)=0.2, \mathrm{q}(0)=0.07, \mathrm{i}(0)=0.3$ yang disimulasikan menggunakan Maple 2020 diperoleh hasil berikut. 


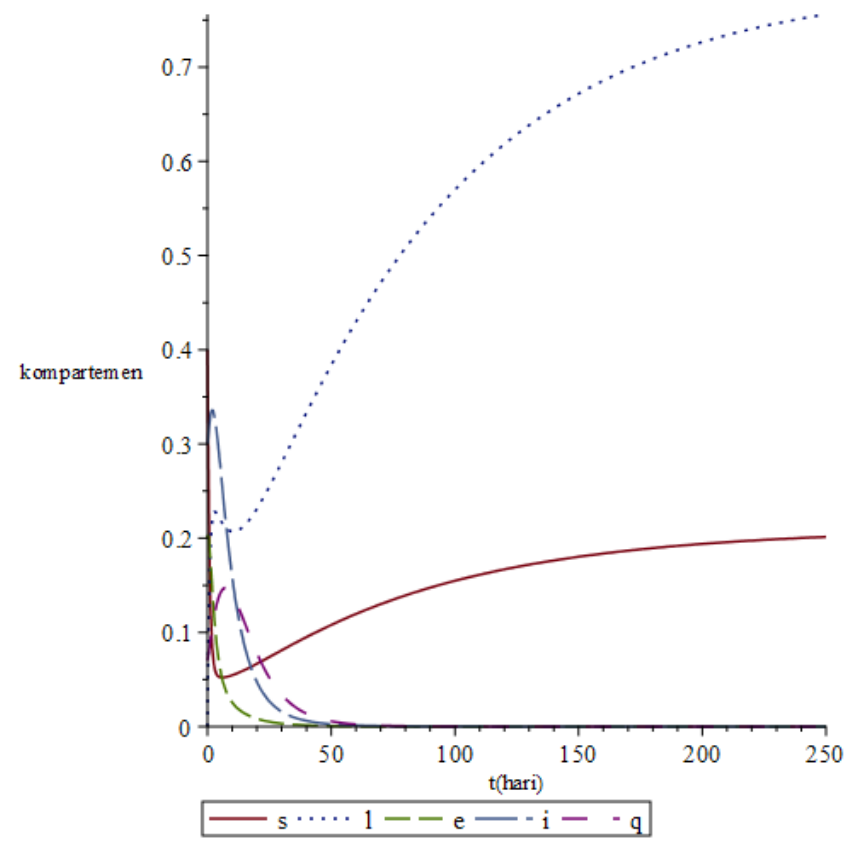

Gambar 3. Simulasi sistem (4) titik ekulibrium endemik

Berdasarkan simulasi yang dilakukan populasi individu rentan (S) naik hingga hari ke - 700 menuju titik 0.2067858770 dan stabil pada titik tersebut. Populasi individu yang melakukan lockdown (L) naik hingga hari ke -600 menuju titik 0.7784880075 dan stabil pada titik tersebut. Populasi individu laten (E) turun hingga hari ke - 70 menuju titik 0.0003869054209 dan stabil pada titik tersebut. Populasi individu terinfeksi (I) turun hingga hari ke -80 menuju titik 0.0008901789963 dan stabil pada titik tersebut. Populasi individu yang melakukan karantina (Q) turun hingga hari ke - 130 menuju titik 0.0006206907177 dan stabil pada titik tersebut. Kesimpulan yang dapat diperoleh dari simulasi ini adalah penyakit akan menetap pada populasi jika $\mathcal{R}_{0}>1$. Hasil ini sesuai dengan Teorema 1 tentang eksistenasi titik ekuilibrium endemik dan sesuai Teorema pada [5] yang menyatakan bahwa jika $\mathcal{R}_{0}>1$, penyakit akan menyebar dan menuju titik ekuilibrium endemik.

Berdasarkan Teorema 2 dan hasil simulasi numerik, disimpulkan bahwa penyakit akan menghilang dari populasi jika nilai $R_{0}<1$. Diperhatikan kembali $R_{0}$ yang diberikan oleh Persamaan (7), supaya $R_{0}<1$ dapat dilakukan dengan memperkecil pembilang dan memperbesar penyebut, yaitu dengan memperkecil parameter $\beta$ serta memperbesar parameter $\xi, \eta, \alpha_{1}, \theta_{1}$ dan $\theta_{2}$. Sehingga rekomendasi dari penelitian ini untuk pengendalian wabah penyakit COVID-19 adalah sebagai berikut:

1. Mengintensifkan karantina bagi pasien terinfeksi $\left(\theta_{1}\right)$ maupun karantina bagi orang yang kontak dengan penderita COVID-19 $\left(\theta_{2}\right)$ untuk mengurangi penularan COVID-19.

2. Mengurangi tingkat kontak antara individu terinfeksi dengan individu rentan $\left(\beta_{1}\right)$. Misalnya dengan menghindari kerumunan dan menjaga jarak.

3. Meningkatkan laju kesembuhan individu terinfeksi $\left(\alpha_{1}\right)$. Misalnya dengan membuat obat baru yang dapat menekan laju infeksi COVID-19 dalam tubuh.

4. Memperbesar dan memperlama lockdown atau penguncian wilayah $(\eta)$ untuk menekan persebaran COVID-19 menular ke wilayah lain.

\section{KESIMPULAN}

1. Berdasarkan diagram transfer penyebaran penyakit COVID-19 yang telah disusun pada penelitian ini, diperoleh model penyebaran penyakit COVID-19 SEIR dengan lockdown dan karantina atau model SEIRLQ. Model yang diperoleh berupa sistem persamaan diferensial biasa. 
2. Model matematika penyebaran penyakitCOVID-19 SEIR dengan lockdown dan karantina memiliki satu titik ekuilibrium bebas penyakit $E_{1}=\left(\frac{\mu+\delta}{\mu+\delta+\eta}, \frac{\eta}{\mu+\delta+\eta}, 0,0,0\right)$ yang memiliki kestabilan titik ekuilibrium stabil asimtotik lokal saat $\mathcal{R}_{0}<1$ dan satu titik ekuilibrium endemik $E_{2}=\left(s^{*}, l^{*}, e^{*}, i^{*}, q^{*}\right)$ yang eksistensinya bergantung $\mathcal{R}_{0}$ yakni ada jika $\mathcal{R}_{0}>1$.

3. Diperoleh bilangan reproduksi dasar penyakit COVID-19 dengan lockdown dan karantina. $R_{0}=\frac{\varepsilon \beta_{1}(\mu+\delta)}{\left(\mu+\varepsilon+\theta_{2}+\xi\right)\left(\mu+\alpha_{1}+\theta_{1}\right)(\mu+\delta+\eta)}$.

4. Berdasarkan analisis kestabilan titik ekuilibrium dan simulasi numerik disimpulkan penyakit akan hilang jika $\mathcal{R}_{0}<1$ dan akan menetap pada populasi jika $\mathcal{R}_{0}>1$. Berdasarkan hal tersebut, langkah yang dapat dilakukan agar penyakit tidak menjadi wabah adalah mengintensifkan karantina, mengurangi tingkat kontak antara individu terinfeksi dengan individu rentan, meningkatkan laju kesembuhan individu terinfeksi, memperbesar dan memperlama lockdown atau penguncian wilayah.

\section{DAFTAR PUSTAKA}

[1] A. Lee, "Wuhan novel coronavirus (COVID-19): why global control is challenging?," Public Health, vol. 179. pp. A1-A2, 2020, doi: 10.1016/j.puhe.2020.02.001.

[2] M. Ali, S. T. H. Shah, M. Imran, and A. Khan, "The role of asymptomatic class, quarantine and isolation in the transmission of COVID-19," Journal of Biological Dynamics, vol. 14, no. 1. pp. 389-408, 2020, doi: 10.1080/17513758.2020.1773000.

[3] E. Soewono, "On the analysis of Covid-19 transmission in Wuhan, Diamond Princess and Jakarta-cluster," Commun. Biomath. Sci., vol. 3, no. 1, pp. 9-18, 2020, doi: 10.5614/cbms.2020.3.1.2.

[4] R. Ghanam, E. L. Boone, and A.-S. G. Abdel-Salam, "SEIRD MODEL FOR QATAR COVID-19 OUTBREAK: A 1 Introduction 2 The SEIRD Model," Lett. Biomath. - An Int. J., vol. 0, no. 0, pp. 1-11, 2020.

[5] A. rahman J. Mumbu and A. K. Hugo, "Mathematical modelling on COVID-19 transmission impacts with preventive measures: a case study of Tanzania," Journal of Biological Dynamics, vol. 14, no. 1. pp. 748-766, 2020, doi: 10.1080/17513758.2020.1823494.

[6] M. Manaqib, I. Fauziah, and M. Mujiyanti, "Mathematical Model for MERS-COV Disease Transmission with Medical Mask Usage and Vaccination," Inpr. Indones. J. Pure Appl. Math., vol. 1, no. 2, pp. 30-42, 2019, doi: 10.15408/inprime.v1i2.13553.

[7] S. A. M. Yatim and P. S. Kim, "The impact of lockdowns, contact tracing, and other control measures on the transmission of COVID-19 in Malaysia," Lett. Biomath., pp. 1-15, 2020, [Online]. Available: https://lettersinbiomath.journals.publicknowledgeproject.org/index.php/lib/article/view/371.

[8] Y. Xiang, Y. Jia, L. Chen, L. Guo, B. Shu, and E. Long, "COVID-19 epidemic prediction and the impact of public health interventions: A review of COVID-19 epidemic models," Infect. Dis. Model., vol. 6, no. 24, pp. 324-342, 2021, doi: 10.1016/j.idm.2021.01.001.

[9] X. Zhang, R. Ma, and L. Wang, "Predicting turning point, duration and attack rate of COVID-19 outbreaks in major Western countries," Chaos, Solitons and Fractals, vol. 135, 2020, doi: 10.1016/j.chaos.2020.109829.

[10] WHO, "WHO director-general's opening remarks." https://www.who.int/dg/speeches/\%0Adetail/who-director-general-sopening-remarks-at-the-media-briefing-on\%02covid-19-11-march-2020. (accessed Feb. 11, 2021).

[11] Komite Pengendalian Covid-19 dan Pemulihan Ekonomi Nasional (KPC PEN), "Peta Sebaran COVID-19." https://covid19.go.id/peta-sebaran-covid19 (accessed Feb. 11, 2021).

[12] M. Amaku et al., "Modelling the test, trace and quarantine strategy to control the COVID-19 epidemic in the state of São Paulo, Brazil," Infect. Dis. Model., vol. 6, pp. 46-55, 2021, doi: 10.1016/j.idm.2020.11.004.

[13] Komite Pengendalian Covid-19 dan Pemulihan Ekonomi Nasional (KPC PEN), "Keputusan Ketua Satuan Tugas Penanganan COVID-19 Nomor 9 Tahun 2021.” https://covid19.go.id/p/regulasi/keputusan-ketua-satuan-tugas-penanganan-covid-19nomor-9-tahun-2021 (accessed Feb. 11, 2021).

[14] I. Taufiq and D. Agustito, "Application of Mathematical Models Two Predators and Infected Prey by Pesticide Control in Nilaparvata Lugens Spreading in Bantul Regency," Inpr. Indones. J. Pure Appl. Math., vol. 2, no. 1, pp. 41-50, 2020, doi: 10.15408/inprime.v2il.14887.

[15] M. Manaqib, "Pemodelan Matematika Infiltrasi Air Pada Saluran Irigasi Alur,” J. Mat. “MANTIK, ” vol. 3, no. 1, p. 25, 2017, doi: 10.15642/mantik.2017.3.1.25-31.

[16] N. Inayah, M. Manaqib, N. Fitriyati, and I. Yupinto, "Model Matematika Dari Penyebaran Penyakit Pulmonary Tuberculosis Dengan Penggunaan Masker Medis," BAREKENG J. Ilmu Mat. dan Terap., vol. 14, no. 3, pp. 461-472, 2020, doi: 10.30598/barekengvol14iss3pp461-472.

[17] G. O. Fosu, J. M. Opong, and J. K. Appati, "Construction of Compartmental Models for COVID-19 with Quarantine, Lockdown and Vaccine Interventions,” SSRN Electron. J., pp. 1-15, 2020, doi: 10.2139/ssrn.3574020.

[18] M. Imran, M. Wu, Y. Zhao, E. Beşe, and M. J. Khan, "Mathematical Modelling of SIR for COVID-19 Forecasting," no. February, 2021, doi: 10.24205/03276716.2020.2018.

[19] M. Ivanova and L. Dospatliev, "DATA ANALYTICS AND SIR MODELING OF COVID-19 IN BULGARIA,” Int. J. Apllied Math., vol. 33, Jan. 2021, doi: 10.12732/ijam.v33i6.10.

[20] Z. Liao, P. Lan, Z. Liao, Y. Zhang, and S. Liu, "TW-SIR: time-window based SIR for COVID-19 forecasts," Sci. Rep., vol. 10, no. 1, pp. 1-16, 2020, doi: 10.1038/s41598-020-80007-8. 
[21] A. Mitra, "Covid-19 in India and Sir Model," J. Mech. Contin. Math. Sci., vol. 15, no. 7, 2020, doi: 10.26782/jmcms.2020.07.00001.

[22] M. Ala'raj, M. Majdalawieh, and N. Nizamuddin, "Modeling and forecasting of COVID-19 using a hybrid dynamic model based on SEIRD with ARIMA corrections," Infect. Dis. Model., vol. 6, pp. 98-111, 2021, doi: 10.1016/j.idm.2020.11.007.

[23] M. Chinazzi et al., "The effect of travel restrictions on the spread of the 2019 novel coronavirus (2019-nCoV) outbreak," medRxiv, vol. 9757, no. March, pp. 1-12, 2020, doi: 10.1101/2020.02.09.20021261.

[24] D. Kai, G. P. Goldstein, A. Morgunov, V. Nangalia, and A. Rotkirch, "Universal masking is urgent in the COVID-19 pandemic: SEIR and agent based models, empirical validation, policy recommendations," arXiv, 2020.

[25] A. J. Kucharski et al., "Early dynamics of transmission and control of COVID-19: A mathematical modelling study," medRxiv. 2020, doi: 10.1101/2020.01.31.20019901.

[26] C. Wang et al., "Evolving epidemiology and impact of non-pharmaceutical interventions on the outbreak of coronavirus disease 2019 in Wuhan, China," medRxiv, 2020, doi: 10.1101/2020.03.03.20030593.

[27] J. T. Wu, K. Leung, and G. M. Leung, "Nowcasting and Forecasting the Potential Domestic and International Spread of the 2019-nCoV Outbreak Originating in Wuhan, China: A Modeling Study," Obstetrical and Gynecological Survey, vol. 75 , no. 7. pp. 399-400, 2020, doi: 10.1097/01.ogx.0000688032.41075.a8.

[28] Z. Yang et al., "Modified SEIR and AI prediction of the epidemics trend of COVID-19 in China under public health interventions," J. Thorac. Dis., vol. 12, no. 3, pp. 165-174, 2020, doi: 10.21037/jtd.2020.02.64.

[29] S. Zhao et al., "Preliminary estimation of the basic reproduction number of novel coronavirus (2019-nCoV) in China, from 2019 to 2020: A data-driven analysis in the early phase of the outbreak," Int. J. Infect. Dis., vol. 92, pp. 214-217, 2020, doi: 10.1016/j.ijid.2020.01.050.

[30] W. O. Kermack and A. G. McKendrick, "A Contribution to the Mathematical Theory of Epidemics," Proc. R. Soc. London. Ser. A, Contain. Pap. a Math. Phys. Character, vol. 115, no. 772, pp. 700-721, Feb. 1927, [Online]. Available: http://www.jstor.org/stable/94815.

[31] J. A. P. Heesterbeek and M. G. Roberts, "The type-reproduction number T in models for infectious disease control," Math. Biosci., vol. 206, no. 1, pp. 3-10, 2007, doi: 10.1016/j.mbs.2004.10.013.

[32] Badan Pusat Statistik, "Hasil Sensus Penduduk 2020." https://www.bps.go.id/pressrelease/2021/01/21/1854/hasil-sensuspenduduk-2020.html.

[33] B. K. Mishra et al., "COVID-19 created chaos across the globe: Three novel quarantine epidemic models," Chaos, Solitons and Fractals, vol. 138, p. 109928, Sep. 2020, doi: 10.1016/j.chaos.2020.109928.

[34] A. B. Gumel, E. A. Iboi, C. N. Ngonghala, and E. H. Elbasha, "A primer on using mathematics to understand COVID-19 dynamics: Modeling, analysis and simulations," Infectious Disease Modelling, vol. 6. pp. 148-168, 2021, doi: 10.1016/j.idm.2020.11.005.

[35] B. Tang, N. L. Bragazzi, Q. Li, S. Tang, Y. Xiao, and J. Wu, "An updated estimation of the risk of transmission of the novel coronavirus (2019-nCov)," Infectious Disease Modelling, vol. 5. pp. 248-255, 2020, doi: 10.1016/j.idm.2020.02.001.

[36] B. Tang et al., "The effectiveness of quarantine and isolation determine the trend of the COVID-19 epidemics in the final phase of the current outbreak in China," International Journal of Infectious Diseases, vol. 95. pp. 288-293, 2020, doi: 10.1016/j.ijid.2020.03.018. 